\title{
NEW MUSEOLOGY AND TOURIST EXPERIENCE IN CULTURAL TOURISM - THE CASE STUDY OF A MUSEUM IN BUDAPEST
}

\section{Melinda JÁSZBERÉNYI ${ }^{a, *}$, Katalin ÁSVÁNYI ${ }^{\mathrm{b}}$, Dorottya BODNÁR ${ }^{c}$}

a), c) Corvinus University of Budapest, Department of Tourism, Budapest, Hungary

b) Corvinus University of Budapest, Department of Marketing, Media and Design Communication, Budapest, Hungary

Please cite this article as:

Article History:

Jászberényi, M., Ásványi, K. and Bodnár, D., 2018. Received: 1 August 2017 New museology and tourist experience in cultural Accepted: 29 November 2017 tourism - The case study of a museum in Budapest.

Review of Economic Studies and Research Virgil

Madgearu, 11(1), pp.41-53.

doi: 10.24193/RVM.2018.11.20.

Abstract: New museology is a new paradigm which draws attention to the fact that it is not enough to make high culture available only to certain privileged people. To socialize the culture is necessary so the whole society could experience the museum visit. In our study we examined our main research question in the case of the Hungarian National Gallery, as what types of consumer experiences foreign tourists gain in a museum. Primary and secondary research was made to analyse the research field. Based on consumer feedback, we can say that in the Hungarian National Gallery the consumer experience is mostly characterized by educational and aesthetic experience, which is complemented by the entertainment experience, but the escapist one is completely absent. We also formulate conclusions from the results and proposals to improve the customer experiences.

Key words: new museology; museum; cultural tourism; experience JEL Classification: L83; Z11; Z32

(C) 2018 Alma Mater Publishing House. All rights reserved.

* Corresponding author. E-mail address: melinda.jaszberenyi@gmail.com. 


\section{References}

1. Bodnár, D., 2014. IV. turisztikai attrakciók vonzerejének növelése mobil applikációkkal, digitális eszközökkel. In: M. Jászberényi, ed. 2014. Kulturális turizmus sokszínüsége, Nemzeti Közszolgálati és Tankönyv Kiadó, pp.131-142.

2. Jászberényi, M., 2014. Kulturális turizmus elméleti háttere. In: M. Jászberényi, ed. 2014. Kulturális turizmus sokszínüsége, Nemzeti Közszolgálati és Tankönyv Kiadó, pp.11-22.

3. Michalkó, G. and Rátz, T., 2005. A kulturális turizmus élménygazdaságtani szempontjai. In: G. Egyedi and K. Keresztély, eds. 2005. A magyar városok kulturális gazdasága, Budapest: MTA Társadalomkutató Központ, pp.123-141.

4. Pine, B.J. and Gilmore, J.H., 1998. Welcome to the experience economy. Harvard Business Review, 76(4), pp.97-105.

5. Pine, B.J. and Gilmore, J.H., 1999. The Experience Economy: Work is Theatre and Every Business a Stage. Boston: Harvard Business School Press.

6. Sulyok, J., 2005. Kulturális turizmus az európai városokban. Turizmus Bulletin, 9(3), pp.18-29.

7. WTO-ETC (World Tourism Organization - European Travel Commission), 2004. City Tourism and Culture - The European Experience.

8. Zátori, A., 2014. Élményszemlélet a turizmusban: A turisztikai élményteremtés koncepciói. Turizmus Bulletin, 16(2), pp.51-60. 